\title{
Dissipation of Chlorpyrifos in a Malaysian Agricultural Soil: A Comparison between a Field Experiment and Simulation by the VARLEACH and PERSIST Models
}

(Pelesapan Chlorpirifos dalam Tanah Pertanian Malaysia: Perbandingan antara Kajian Lapangan dan Simulasi Model VARLEACH dan PERSIST)

\author{
ISMAIL, B.S.*, HALIMAH, M., TAN, Y.A. \& TAYEB, M.A.
}

\begin{abstract}
A comparison of the dissipation of chlorpyrifos in a Malaysian agricultural soil was undertaken using data from a field experiment and simulation by the PERSIST model. The study was carried out at an oil palm estate located close to the Kuala Lumpur International Airport (KLIA), Sepang, Selangor (for field experiment). The plots were treated with chlorpyrifos at the manufacturer's recommended dosage. Soil samples were collected according to the sampling schedule at intervals of $0,1,3,7,14,21,30,60$ and 90 days. Residues of chlorpyrifos in soil from the field trial were analyzed in the laboratory. Simulation of chlorpyrifos leaching and persistency was done using two computer-run software VARLEACH And PERSIST. Generally, predicted data for chlorpyrifos residue obtained using the VARLEACH and PERSIST models was found to be well matched with the observed data from the field trial. The PERSIST Prediction for chlorpyrifos residue in soils planted with oil palm trees was found to be accurate and conformed to the results observed in the field trial.
\end{abstract}

Keywords: Chlorpyrifos; leaching; persist; soil; VARLEACH and PERSIST model

\section{ABSTRAK}

Perbandingan pelesapan chlorpirifos dalam tanah pertanian Malaysia telah dijalankan dengan menggunakan data daripada kajian lapangan dan simulasi dengan model PERSIST. Kajian ini telah dijalankan di sebuah ladang kelapa sawit yang terletak berhampiran dengan Lapangan Terbang Antarabangsa Kuala Lumpur (KLIA), Sepang, Selangor (untuk kajian lapangan). Plot telah dirawat dengan chlorpirifos pada dos yang disyorkan pengeluar. Sampel tanah telah dikumpulkan mengikut jadual persampelan pada sela 0, 1, 3, 7, 14, 21, 30, 60 dan 90 hari. Sisa chlorpirifos dalam tanah daripada percubaan lapangan dianalisis di dalam makmal. Simulasi chlorpirifos larut lesap dan ketegaran dilakukan menggunakan komputer melalui perisian VARLEACH dan PERSIST. Secara umumnya, peramalan data untuk sisa chlorpirifos diperoleh menggunakan model VARLEACH dan PERSIST didapati padan dengan data yang dicerap daripada percubaan lapangan. Ramalan PERSIST untuk sisa chlorpirifos dalam tanah yang ditanam dengan pokok kelapa sawit didapati tepat dan serupa dengan keputusan yang diperhatikan dalam percubaan lapangan.

Kata kunci: Berlarutan; chlorpirifos; larut lesap; model VARLEACH dan PERSIST; tanah

\section{INTRODUCTION}

In modern agricultural practices, pesticides are used in order to reduce yield loss caused by pests although it is already known that excessive pesticide application could cause environmental problems. Bypass flow (overland and vertically through macro pores) has been identified as an important mechanism for transportation of pesticides to surface and ground water (Gustafson 1993; Nicholls 1994). Pesticides can be transported by bypass flow either in solution or adsorbed to suspended or colloidal matter. Khakural et al. (1995) studied the properties of vertical bypass flow, whereby a lysimeter was used to measure suspended and colloidal matter in leachates. Vertical bypass flow can result in poor pest control, crop injury, and increased loss of pesticide or accumulation of pesticides in the soil (Leistra 1971; Wagenet \& Rao
1990). The degree of damage suffered by crops varied with the aggregate stability and pore-size distribution of the topsoil (Ismail et al. 2004). Also, continuous use of pesticides may cause contamination of surface and ground water as observed in several parts of the world (Trevisan et al. 2000; Walker \& Barners 1981). The degree of pollution is exacerbated if it involves persistent pesticides. The widespread use of pesticides has caused concerns about environmental contamination. Farmers tend to apply pesticides more frequently and sometimes at high doses in order to ensure effective control of insect pests. Preliminary studies have shown that chlorothalonil, a chlorinated fungicide as well as chlorphyrifos and profenofos, which are organophosphate insecticides, are being widely used at the vegetable farms of Cameron Highlands, Malaysia. In many countries, significant 
amounts of pesticides detected in ground and surface water have been found to be rising steadily (Ismail et al. 2015 c). However, information on pesticide contamination in the Malaysian agro ecosystems is limited (Cheah et al. 1997). The present study was conducted to examine the leaching potential of chlorothalonil, chlorpyrifos and profenofos in the vegetable agro ecosystems in Cameron Highlands, Malaysia.

Studies on the fate of pesticides are mostly based on laboratory incubation and field studies. The laboratory incubation studies determine the behavior of pesticides under controlled- environmental conditions so that specific factors that affect pesticide fate can be identified whereas field studies reflect the actual fate of the pesticides under natural environmental conditions. Projecting pesticide behavior in a diverse range of conditions based on both studies is not practical as cost, labor and time are the limiting factors. Therefore modeling of the pesticide fate is a means of obtaining results faster. Pesticide modeling is carried out using computer software, whereby a logarithm of complex mathematical equations is utilized.

PERSIST is a specific computer software designed by Walker in 1978 to predict the persistence of pesticides in the soil. It has been used to successfully predict pesticide persistence in the soils of the UK and USA using parameters derived from laboratory incubation studies (Brown et al. 1999; Wauchope \& Duffy 1992). Studies comparing the observed and predicted residues under tropical conditions such as those found in Malaysia are very limited (Ismail $\&$ Kalithasan 2002). A modeling study using the Hornsby Index, Attenuation Factor and CMLS on 14 pesticides commonly used in cabbage and chrysanthemum farms at the Cameron Highlands, Malaysia demonstrated that of the 14 pesticides, methamidophos had the highest leaching potential (Tayeb et al. 2015b).

Cameron Highlands has been the premier vegetable growing area in Malaysia (Halimah et al. 2016a; Ismail et al. 2013; Tayeb et al. 2015a). Most of the farmers in Cameron Highlands apply pesticides as part of their routine agricultural practice. The pesticides have been used intensively because of high infestation from insect pest populations in the area probably due to the conducive high humidity (Walker 1978). The fungicide chlorothalonil and the organophosphate insecticides such as chlorpyrifos and profenofos, have been widely used, by the farmers. The three pesticides are broad-spectrum, being used to control fungal diseases as well as insect pests of vegetables, fruits, ornamental plants, turf and other agricultural crops.

The study comparing the dissipation of the three pesticides in a field experiment with one using the PERSIST simulation model would help to understand the fate of the pesticides in tropical countries such as Malaysia. Therefore the main objective of the study was to investigate the credibility of the PERSIST model in predicting pesticide residues under tropical conditions like those found in Malaysia.

\section{MATERIALS AND METHODS}

\section{FIELD EXPERIMENT}

Site selection The study was conducted in an oil palm plantation located 6-7 $\mathrm{km}$ from the Kuala Lumpur International Airport (KLIA), and owned by the Malaysian Agricultural and Horticultural Sdn. Bhd. (MAAH) (Halimah et al.2010). The plantation was located is at an altitude of $16.3 \mathrm{~m}$, with the geographical coordinates of $2^{\circ} 44^{\prime} \mathrm{N}$ and $101^{\circ} 42^{\prime} \mathrm{E}$. The number of palms planted/ha was 142 . The experimental site was flat with nine plots, each measuring approximately $0.33 \mathrm{ha}$, and containing $6 \times 7=42$ palms. Chlorpyrifos was applied to manufacturer's recommended dosage. Each treatment was replicated thrice using the randomized block design.

Seeding and treatments The trial was conducted from July 2002 to September 2002. The plots were sprayed with chlorpyrifos (Dursban ${ }^{\circledR} 75$ E) using a knapsack sprayer. Chlorpyrifos used in the treatments contained $21.2 \%$ a.i. It was applied as an aqueous solution to the palms, using the conventional knapsack sprayer (nozzle $5 / 64$, fine droplets). To prepare the manufacturer's recommended dosage, 18 of the chemical products were diluted separately in $9 \mathrm{~L}$ water. $150 \mathrm{~mL}$ of the diluted product were sprayed on each palm: at the bole for $2 \mathrm{~s}$ and at the crown for $4 \mathrm{~s}$.

Soil sampling Soil samples were collected in triplicate from $0-50 \mathrm{~cm}$ depth using a soil auger. The samples were taken from -1 (day before spraying), to $1,3,7,14$, $21,30,60$ and 90 days after treatment. The soil samples were air-dried, sieved through a $2 \mathrm{~mm}$ mesh and stored in black polyethylene bags at $-4^{\circ} \mathrm{C}$ prior to analysis. The soil constituted a loam with $30.6 \%$ moisture, $6.08 \%$ total organic carbon, $17 \%$ clay, $31.25 \%$ silt, $51.25 \%$ fine sand and $0.3 \%$ coarse sand, giving a total sand content of $51.55 \%$. The $\mathrm{pH}$ of the soil was 4.97 .

GC analysis The content of chlorpyrifos in the extracts was determined using an Agilent Model 5890 (US) GC equipped with an OI Analytical Model 5360 and a halogenspecific detector (XSD) with a non-polar capillary column of $100 \%$ dimethylpolysiloxane (DB-1), $30 \mathrm{~m}$ length, 0.25 $\mathrm{mm}$ i.d. and $0.25 \mathrm{~mm}$ film thickness. Nitrogen was used as the carrier gas at a flow rate of $1 \mathrm{~mL} / \mathrm{min}$. The injector and detector temperature levels were set at $250^{\circ} \mathrm{C}$ and $300^{\circ} \mathrm{C}$, respectively. The oven temperature program was initially set at $40^{\circ} \mathrm{C}$ for one min, raised further to $150^{\circ} \mathrm{C}$ at the rate of $15^{\circ} \mathrm{C} / \mathrm{min}$, raised to $260^{\circ} \mathrm{C}$ at the rate of $25^{\circ} \mathrm{C} /$ $\mathrm{min}$ and the temperature maintained for $5 \mathrm{~min}$. The volume of injection was $3 \mathrm{~mL}$. There were three replicates and each solution was injected twice.

Recovery study The soil (5 g) was treated with chlorpyrifos at five concentrations viz. 0.001, 0.05, 0.1, 0.2 and $1.0 \mathrm{mg} / \mathrm{g}$. The chlorpyrifos was extracted from the 
soil using liquid solid extraction and determined using a gas chromatograph (GC) equipped with GC-XSD.

Extraction of Chlorpyrifos from the Soil The method extraction was similar as reported by Halimah et al. (2010). Five g samples of chlorpyrifos-free soil were placed into $250 \mathrm{~mL}$ conical flasks. The samples were spiked with the standard chlorpyrifos solutions in hexane (0.02 to 5.0 $\mathrm{mg} / \mathrm{mL}$ ), to give the equivalent concentrations of 0.001 to $1 \mathrm{mg} / \mathrm{g}$ soil. The contents were then mixed using a vortex mixer for $10 \mathrm{~s}$ and the mixtures were allowed to homogenize (left standing for $20 \mathrm{~min}$ ). $20 \mathrm{~mL}$ of a mixture of hexane: ethyl acetate (95:5) were added to each conical flask and the contents mixed thoroughly again for $30 \mathrm{~s}$ on the vortex mixer. Each conical flask was then placed in an ultrasonic bath for $20 \mathrm{~min}$, after which the contents were transferred into a test tube and centrifuged at 3,500 rpm at $26^{\circ} \mathrm{C}$ for $10 \mathrm{~min}$. The supernatant $(10 \mathrm{~mL})$ was then transferred into a graduated micro vial using a Pasteur pipette. The solution was evaporated to dryness using a nitrogen-evaporator and the residue re-dissolved in $5 \mathrm{~mL}$ hexane. This was then mixed in an ultrasonic bath for $3 \mathrm{~s}$ prior to injection into the GC-XSD.

Prediction of Persistence by the PERSIST Model The PERSIST modeling was undertaken using a personal computer. Input of data required for the simulations were daily maximum and minimum air temperatures and daily rainfall records. The daily weather data was obtained from the KLIA weather station. The weather data was taken from the day of the first treatment to day-90 and was used as an input to simulate as close as possible the weather conditions of the field under study. The model also required input of soil physical properties such as field capacity (at $5 \mathrm{kPa}$ suction) and soil bulk density. The pesticide properties such as half-life with regard to soil moisture at specific temperatures were also required. The half-life value for each of the three pesticides was derived from the field study. The known rate of pesticide application was also a requirement. The geographical location of the plot such as its latitude and altitude was a prerequisite. The output of the simulation came in the standard column format with headings: DAYS (days after application), CONC (residual concentration of pesticide, $\%$ of initial), SM (soil moisture content, \%), ST (mean soil temperature, ${ }^{\circ} \mathrm{C}$ ), EO (calculated potential pan evaporation, $\mathrm{mm}$ ) and HL (calculated halflife, days).

\section{RESULTS AND DISCUSSION}

\section{STANDARD CALIBRATION CURVE AND RECOVERY OF CHLORPYRIFOS}

The linear regression $\left(\mathrm{r}^{2}\right)$ was found to be 0.9993 and the equation derived from the calibration curve was $y=$ $309.99 x-1.6367$, where $y$ is the area of chlorpyrifos and $x$ the concentration of chlorpyrifos in $\mu \mathrm{g} / \mathrm{mL}$. The external standard of chlorpyrifos was used to identify the peak and calculate the recovery of chlorpyrifos from the spiked samples. The recovery of chlorpyrifos at level of 0.001 to $1.0 \mu \mathrm{g} / \mathrm{g}$ from the spiked soil samples ranged from 88 $99 \%$ with standard deviations of 2.0 to $7.5 \%$ (Table 1 ). The minimum detection limit of chlorpyrifos was 0.001 $\mathrm{mg} / \mathrm{g}$ and was calculated as five times the chromatographic noise level of the standard solution. The results showed that the method used to extract chlorpyrifos from the soil is reproducible and acceptable.

TABLE 1. Recovery of chlorpyrifos from spiked soil samples

\begin{tabular}{ccc}
\hline $\begin{array}{c}\text { Amount added } \\
\mu \mathrm{g} / \mathrm{kg}\end{array}$ & $\begin{array}{c}\text { Mean recovery } \\
(\%) n=5\end{array}$ & $\begin{array}{c}\text { Relative standard } \\
\text { deviation }(\%)\end{array}$ \\
\hline 1 & 99 & 2.0 \\
0.2 & 88 & 2.5 \\
0.1 & 92 & 5.9 \\
0.05 & 96 & 3.9 \\
0.001 & 91 & 7.5 \\
\hline
\end{tabular}

Figure 1(a), 1(b) and 1(c) shows the chromatograms of GC-XSD for the chlorpyrifos standard solution of $0.02 \mu \mathrm{g} /$ $\mathrm{mL}$, the untreated sample of soil and a spiked soil sample containing $0.02 \mu \mathrm{g} / \mathrm{g}$ of chlorpyrifos, respectively. The retention time of chlorpyrifos was around $12.75 \mathrm{~min}$.

Table 2 shows the residue concentrations of chlorpyrifos in the soil. Chlorpyrifos degraded rapidly and was detected at of depth of $0-10 \mathrm{~cm}$ for five days after treatment. Chlorpyrifos was not detected below the $10 \mathrm{~cm}$ depth and this could be due to the physical characteristics of the soil. Previous studies have demonstrated that

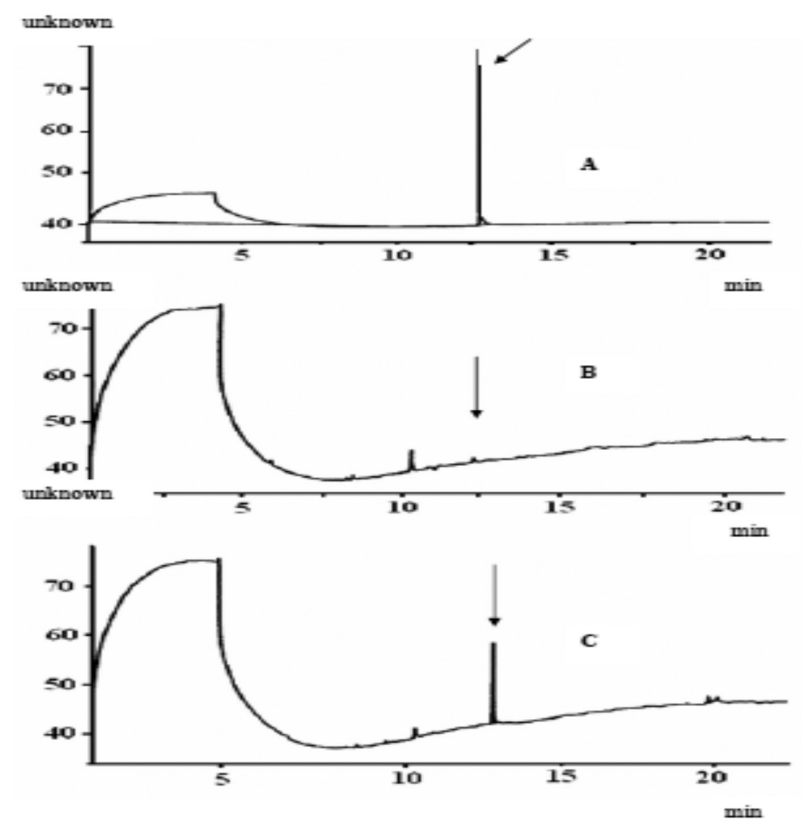

FIGURE 1. GC-XSD Chromatograms of (a) Chlorpyrifos standard solution, $0.02 \mu \mathrm{g} / \mathrm{mL}$, (b) Untreated sample of soil and (c) Spike soil sample containing $0.02 \mu \mathrm{g} / \mathrm{g}$ of chloropyrifos 
several factors, such as adsorption of the pesticide to soil particles, water solubility of the pesticide, volume of leachate, $\mathrm{pH}$ and soil texture, can influence the leaching of the pesticides through the soil (Ismail et al. 2015d; Nicholls et al. 1982). Other factors such as volatilization, runoff, leaching, chemical and biological degradation, absorption and photolysis could enhance the degradation rate especially under the Malaysian weather conditions. The high temperature, humidity and rainfall throughout the year could have contributed to the rapid loss of the pesticides from the experimental plot. The accelerated pesticide degradation and dissipation under Malaysian conditions could be the cause. One possible factor could be non-uniform spraying of the pesticide that could have caused uneven pesticide distribution in the studied plots. Another reason could be that the sampling point could have fallen within an area that received less spray.

TABLE 2. The degree of agreement and accuracy of VARLEACH modeling for fluroxypyr residues in the soil

\begin{tabular}{ccc}
\hline DAY & $\begin{array}{c}\text { CRM for } \\
\text { VARLEACH }\end{array}$ & $\begin{array}{c}\text { \% Difference between } \\
\text { observed and VARLEACH }\end{array}$ \\
\hline 0 & 1 & 0 \\
1 & 1.05 & 5.7 \\
5 & 1.02 & 2.3 \\
7 & - & - \\
14 & - & - \\
\hline
\end{tabular}

\section{PERSIST PREDICTION}

PERSIST Prediction for Chlorpyrifos Figure 2 shows the PERSIST Prediction and observed results for chlorpyrifos, obtained from the computer program and the field trial (observed value), respectively. It was observed that there was a similar pattern in the dissipation rates for the predicted and observed results. The values were very close; however the predicted values were higher than the observed value for chlorpyrifos. This observation was similar to that reported by Walker $(1996,1987)$, whereby the predicted values were overestimated.

The degree of agreement between the predicted and the observed values was evaluated using the coefficient of residual mass (Halimah et al. 2016b; Ismail et al. 2015a; Maznah et al. 2015). The coefficient of residual mass (CRM) is obtained by dividing the predicted value by the observed value. A value of CRM $>1$ indicates that the model over predicted the observed value, while a value of $\mathrm{CRM}<1$ indicates that the model under predicted the observed value. A perfect agreement between predicted and observed values would be characterized by the value CRM $=1$. If the difference is within $30 \%$ of the observed value then the model can be considered as practically accurate in predicting residues for the subsequent crops.

Table 3 shows the degree of agreement and accuracy of the PERSIST model for estimating chlorpyrifos residues in the soil. The CRM value for PERSIST on the day of spray (Day 0) was 1, indicating that there is perfect agreement between the predicted and observed value (Ismail et al. 2015b; Walker et al. 1996). On the first, third and fifth day after treatment, the CRM value predicted by PERSIST was slightly higher compared to the observed values. Therefore, the predicted PERSIST values were slightly overestimated. Similar findings on the dissipation of fenvalerate (Ismail \& Maznah 2005) and chlorothelonil, chloropyrifos and profenofos in Malaysian agricultural soils were reported (Ismail \& Ngan 2004), where the predicted data derived from the model showed higher values than the observed data.

TABLE 3. The degree of agreement and accuracy of PERSIST modelling for chlorpyrifos residue in the soil

\begin{tabular}{ccc}
\hline DAY & $\begin{array}{r}\text { CRM for } \\
\text { PERSIST }\end{array}$ & $\begin{array}{c}\text { \% Difference between } \\
\text { observed and PERSIST }\end{array}$ \\
\hline 0 & 1 & 0 \\
1 & 1.01 & 1.01 \\
3 & 1.04 & 4.26 \\
5 & 1.2 & 20.84 \\
7 & - & - \\
14 & - & - \\
\hline
\end{tabular}

It was observed that there was no difference between the observed and predicted results on the first day after treatment (DAT 0) in Table 3. However, there was a slight difference between the observed and predicted values on 1 DAT and 3 DAT, which were $1.01 \%$ and $4.26 \%$, respectively. On 5 DAT the difference between the observed and model values was $20.84 \%$. It was observed that the difference in PERSIST value for the observed and predicted value increases as the days after treatment increases. However the PERSIST values were good estimates of the observed values. Therefore, the model can be considered as it was practically accurate in predicting chlorpyrifos residue in the soil planted with oil palm because the difference was is within 30\% (Walker 1978). The PERSIST prediction was that there would be residue up to day 14 after treatment but the observed data indicated that chlorpyrifos was detected up to day 5 only (Figure 2). The PERSIST prediction was that chlorpyrifos would be degraded slower compared to the observed data. This faster degradation could be due to high temperature, which favored microbial growth and probably enhanced both biological and non-biological activity of pesticide dissipation (Boesten \& Van der Linden 1991; Tayeb et al. 2016).

Varleach Pediction for Chlorpyrifos Figure 3 shows the predicted and measured value from the VARLEACH model obtained from the computer programme compared to the field trial (observed value). It was observed that there was a little difference between the measured and predicted values of chlorpyrifos. There was no dissipation on day 0 for the observed and predicted values (Figure 


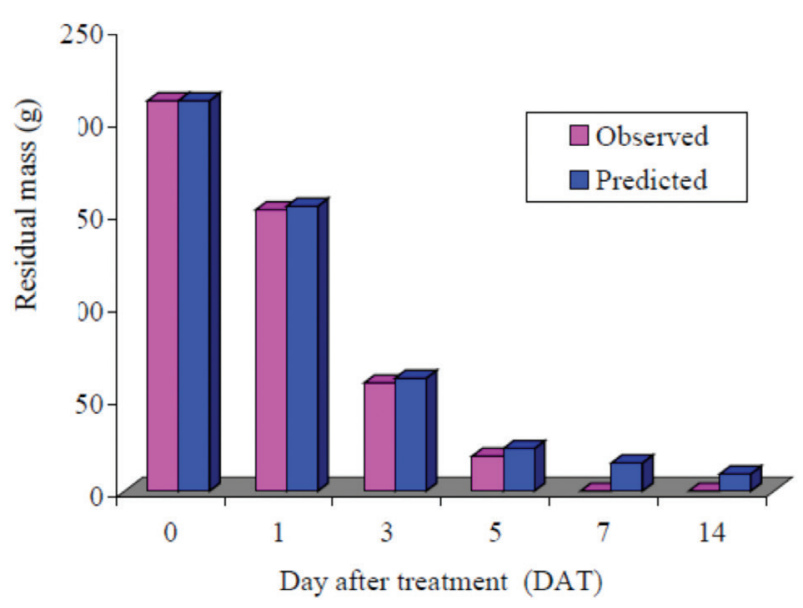

FIGURE 2. Measured and predicted dissipation of chlorpyrifos residue levels in clay loam soil (PERSIST simulation)

3 ). However, the observed values were reduced to $72 \%$ and the predicted values to $80 \%$. On 3 DAT and 5 DAT, the amount of chlorpyrifos was further reduced to $28 \%$ and $32 \%$ for observed and predicted values, respectively. On 7 DAT there was $9 \%$ of chlorpyrifos residue found in the soil for the observed values and $11.6 \%$ of chlorpyrifos for the predicted value. Chlorpyrifos residue was not detected in the field at 14 DAT, but by the VARLEACH simulation, chlorpyrifos was predicted to dissipate completely on DAT 21. The VARLEACH model gave overestimated values compared to the observed values possibly due to weather conditions, which could have favored biodegradation of chlorpyrifos.

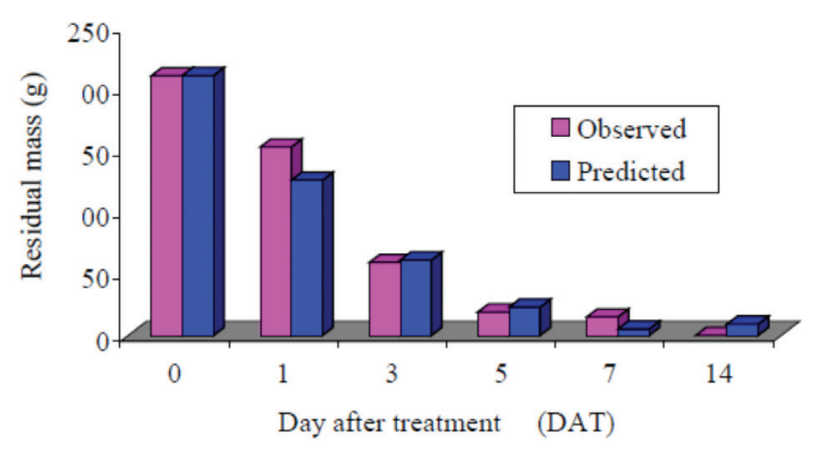

FIGURE 3. Measured and predicted dissipation of chlorpyrifos residue levels in clay loam soil (VARLEACH simulation)

Table 4 shows the CRM and percent difference between the VARLEACH and observed values. The difference in predicted and observed values using the VARLEACH model ranged from $0 \%$ to $21.05 \%$. Since the difference between the observed and predicted values are within $30 \%$, the model can be considered practically accurate in predicting the leaching of chlorpyrifos residues in soil planted with oil palm and therefore the model is acceptable for use. The CRM value was more than 1 , except on 0 DAT when the CRM value was 1 . It was observed that, the CRM value increased as the time interval increased. However, the accuracy of the VARLEACH predictions are acceptable since the difference between the VARLEACH predictions and the observed values is less than $30 \%$. Generally, the predicted values for VARLEACH were very close and only slightly overestimated.

TABLE 4. The degree of agreement and accuracy of VARLEACH modeling for chlorpyrifos residue in soil

\begin{tabular}{ccc}
\hline DAY & $\begin{array}{c}\text { CRM for } \\
\text { PERSIST }\end{array}$ & $\begin{array}{c}\text { \% Difference between } \\
\text { observed and PERSIST }\end{array}$ \\
\hline 0 & 1 & 0 \\
1 & 1.11 & 10.52 \\
3 & 1.17 & 17.24 \\
5 & 1.29 & 21.05 \\
7 & - & - \\
14 & - & - \\
\hline
\end{tabular}

In a previous study, Francaviglia et al. (2000) studied the fate of chlorpyrifos under field conditions at a vegetable farm in Cameron Highlands and compared it with the prediction from the PERSIST simulation model. It was found that the dissipation of the chlorpyrifos in the field experiment was much faster than that predicted by PERSIST. Therefore, the current findings are in agreement with those from the report by Ismail and Ngan (2004).

In conclusion, the present study demonstrated that under the Malaysian conditions, the prediction using PERSIST was slightly over estimated in comparison to the fate of chlorpyrifos in field trial. However the observed data for chlorpyrifos dissipation was in agreement with the predicted values using the PERSIST model.

\section{ACKNOWLEDGMENTS}

Special thanks to Malaysian Palm Oil Board for sponsoring this research. We greatly acknowledge the assistance of Mr. Ayub bin Din (Malaysian Agriculture and Horticulture Sdn. Bhd., KLIA) for his technical assistance.

\section{REFERENCES}

Boesten, J.J.T.I. \& van der Linden, A.M.A. 1991. Modelling of the influence of sorption and transformation on pesticide leaching and persistence. Journal of Environmental Quality 20: 425-435.

Brown, C.D., Baer, U., Günther, P., Trevisan, M. \& Walker, A. 1999. Ring test with the models LEACHP, PRZM-2 and VARLEACH: Variability between model users in prediction of pesticide leaching using a Standard Data Set. Pest Management Science 47(3): 249-258.

Cheah, U.B., Kirkwood, R.C. \& Lum, K.Y. 1997. Adsorptiondesorption and mobility of four commonly used pesticides in Malaysian agricultural soils. Pesticide Science 50: 53-63.

Francaviglia, R., Capri, E., Klein, M., Hosang, J., Aden, K., Trevisan, M. \& Errera, G. 2000. Comparing and evaluating 
pesticide leaching models: Results for the Mancina data set (Italy). Agricultural Water Management 44: 135-151.

Gustafson, D.I. 1993. Advantages pitfalls in the use of models for regulatory control of pesticide usage. Proceedings of 1993 Brighton Crop Protection Conference on Weeds. BCPC Monograph 17.pp. 137-157.

Halimah, M., Ismail, B.S., Nashriyah, M. \& Maznah, Z. $2016 a$. Mobility studies of ${ }^{14} \mathrm{C}$-chlorpyrifos in Malaysian oil palm soils. Bulletin of Environmental Contamination and Toxicology 96: 120-124.

Halimah, M., Sulaiman, N., Ismail, B.S. \& Tayeb, M.A. 2016 b. Dissipation of fluroxypyr in a Malaysian agricultural soil with simulation using the PERSIST and VARLEACH Model. Journal of Oil Palm Research 28(1): 26-33.

Halimah, M., Tan, Y.A., Ismail, B.S. \& Mat, N. 2010. Downward movement of chloropyrifos in the soil of an oil palm plantation in Sepang, Selangor, Malaysia. Journal of Oil Palm Research 22: 721-728.

Ismail, B.S. \& Kalithasan, K. 2002. Measurement and prediction of permethrin persistence in six Malaysia agricultural soils. Australian Journal of Soil Research 40: 1-10.

Ismail, B.S., Mazlinda, M. \& Tayeb, M.A. 2015a. The persistence of deltamethrin in Malaysian agricultural soils. Sains Malaysiana 44(1): 83-89.

Ismail, B.S., Ooi, K.E. \& Tayeb, M.A. 2015b. Laboratory assessment of ${ }^{14} \mathrm{C}$-phenyl metsulfuron-methyl degradation in an oil palm plantation soil. Journal of Oil Palm Research 27(4): 403-416.

Ismail, B.S., Ooi, K.E. \& Tayeb, M.A. 2015c. Degradation of Triazine-2- ${ }^{14} \mathrm{C}$ Metsulfuron-Methyl in soil from an oil palm plantation. PLOS ONE 10(10): 1-15.

Ismail, B.S.,Prayitno, S.\& Tayeb, M.A. 2015d. Contamination of rice field water with sulfonylurea and phenoxy herbicides in the Muda Irrigation Scheme, Kedah, Malaysia. Environmental Monitoring and Assessment 187(7): 406-419.

Ismail, B.S., Mazlinda, M. \& Tayeb, M.A. 2013. Adsorption, desorption and mobility of cypermethrin and deltamethrin in Malaysian soils. International Journal of Plant, Animal and Environmental Sciences 3(4): 23-29.

Ismail, B.S. \& Maznah, Z. 2005. Comparison between field experiment and PERSIST model simulation: Dissipation of fenvalerate in a Malaysian agricultural soil. Bulletin of Environmental Contamination and Toxicology 74: 1143-1150.

Ismail, B.S. \& Ngan, C.K. 2004. Dissipation of chlorothalonil, chlorpyrifos and profenofos in a Malaysian agricultural soil: A comparison between the Field experiment and simulation by the PERSIST model. Journal of Environmental Science and Health 40: 341-353.

Khakural, B.R., Robert, W.C., Koskinen, B.A., Sorensen, D.D. \& Wyse, D.L. 1995. Soil processes and chemical transport. Journal of Environmental Quality 24: 644-655.

Leistra, M. 1971. Diffusion of 1,3-dichloropropene from a plane source in soil. Pesticide Science 2: 75-78.

Maznah, Z., Halimah, M., Ismail, B.S. \& Idris, A.S. 2015. Dissipation of the fungicide hexaconazole in oil palm plantation. Environmental Science and Pollution Research 22: 19648-19657.

Nicholls, P.H. 1994. Simulation of the movement Bentazon in soils using CALF and PRZM models. Journal of Environmental Science and Health 29: 1157-1166.
Nicholls, P.H., Walker, A. \& Baker, R.J. 1982a. Measurements and simulation of the movement and degradation of atrazine and metribuzine in a fallow soil. Pesticide Science 13: 484494.

Tayeb, M.A., Ismail, B.S. \& Khairiatul Mardiana, J. 2015a. Comparison of four different solid phase extraction cartridges for sample clean-up in the analysis of glufosinate ammonium from aqueous samples. International Journal of Chem. Tech. Research 7(6): 2612-2619.

Tayeb, M.A., Ismail, B.S., Khairiatul-Mardiana, J. \& Goh Choo Ta. 2016. Troubleshooting and maintenance of high-performance liquid chromatography during herbicide analysis: An overview. Sains Malaysiana 45(2): 237-245.

Tayeb, M.A., Ismail, B.S., Mardiana-Jansar, K. \& Goh Choo Ta. 2015b. Glufosinate ammonium clean-up procedure from water samples using SPE. AIP Conference Proceedings 1678: 060024(1-7)

Trevisan, M., Errera, G., Vischetti, C. \& Walker, A. 2000. Modelling pesticide leaching in a sandy soil with the VARLEACH model. Agricultural Water Management 44: 367-369.

Wagenet, R.J. \& Rao, P.S.C. 1990. Modeling pesticide fate in soils. In Pesticide in the Soil Environment-Processes, Impacts and Modeling, edited by Cheng, H.H. Madison: Soil Science Society of America, WI. pp. 351-399.

Walker, A., Welch, S.J., Melacini, A. \& Moon, Y.H. 1996. Evaluation of three pesticides leaching models with experimental data for alachlor, atrazine and metribuzin. Weed Research 36: 37-47.

Walker, A. \& Barners, A. 1981. Simulation of herbicide persistence in soil: A revised computer model. Pesticide Science 12: 123-132.

Walker, A. 1987. Evaluation of a simulation model for the prediction of herbicide movement and persistence in soil. Weed Research 27: 143-152.

Walker, A. 1978. Simulation of the persistence of eight soilapplied herbicides. Weed Research 18: 305-313.

Wauchope, R.D. \& Duffy, M.J. 1992. Role of modelling in regulatory affairs: Introduction to the symposium. Weed Technology 6: 671-672.

Ismail, B.S.* \& Tayeb, M.A.

School of Environmental and Natural Resource Sciences

Faculty of Science and Technology

Universiti Kebangsaan Malaysia

43600 UKM Bangi, Selangor Darul Ehsan

Malaysia

Halimah, M. \& Tan, Y.A.

Malaysian Palm Oil Board, P.O. Box 10620

50720 Kuala Lumpur, Federal Territory

Malaysia

*Corresponding author; email: ismail@ukm.edu.my

Received: 29 April 2015

Accepted: 20 April 2016 